\title{
Effectiveness of solution focus brief counseling approach (SFBC) in developing student career adaptability
}

\author{
Mulawarman $^{*}{ }^{1}$, EemMunawaroh $^{2}$, EdwindhaPrafitra Nugraheni $^{3}$ \\ ${ }^{123}$ Universitas Negeri Semarang \\ *) Corresponding author, ఏe-mail: mulawarman@mail.unnes.ac.id
}

\begin{abstract}
Career adaptability is the preparedness role in work and adjustment to changes in working situation in the future. The purpose of this study was to examine Solution Focused Brief Counseling (SFBC) approach in developing career adaptability of students. The method used in this study was a mix method. Subjects selected through a purposive sampling method that is focused on graduate students at the beginning of the semester with a major in Guidance and Counseling Faculty of Education, Semarang State University. Career adaptability in this study consists of four dimensions, concern, control, curiosity and confidence. Stages of Solution Focused Brief Counseling (SFBC) implemented include establishing relationships, identifying a solvable complaint, establishing goals, Designing and Implementing Intervention, and termination, evaluation, and follow-up. The results of this study showed Solution Focused Brief Counseling (SFBC) is effective in improving the adaptability of student career both qualitatively and quantitatively.
\end{abstract}

Keywords: Student Career Adaptability, Solution Focused Brief Counseling (SFBC)

How to Cite: Mulawarman, Munawaroh, E., Nugraheni, E.P. (2016). Effectiveness of Solution Focus Brief Counseling Approach (SFBC) in Developing Student Career Adaptability. Couns-Edu: International Journal of Counseling and Education, 1(1): pp. 9-14. DOI: 10.23916/10-15.0016.11-i33b reproduction in any medium, provided the original work is properly cited. C2016. Indonesian Counselor Association (IKI).

\section{Introduction}

Career adaptability defined as flexibility or willingness of individu to fulfill the tasks, transition and dealing with trauma in career with effective way. Career adaptability consists of four dimensions, concern, control, curiosity, and self-confidence (Savickas and Porfeli 2012: 662). Individual with optimal career adaptability are they focusing an attention to the future career,have good self-control, curiosity to explore themselves and support environment, and confidence to achive the goal (Coolen, 2014; Bimrose, et al, 2011) explain the benefit of career adaptability improvement (1) increasing life satisfaction (Hirschi 2009); (2) increasing commitment to the organization or company (3) helping individuals to find good the quality of work (Koen, et al., 2010; Zikic and Klehe 2006); (4) achievinggoal of career (Grote and Raeder 2009; Heslin, P. A. 2005; O'Connell et al, 2007; Davies, P., \& Pearse, E. 2000; Zikic and Klehe 2006); (6) helping individuals consider the loss of a job; and (7) preparing unpredictable obstacle. This finding showed role of career adaptability to improve individual understanding of the ability, commitment and interest, and quality of work to achieve life satisfaction.

Career development is a lifelong process that begins when individual take an education. Career adaptability result of invididual can be seen from the learning achievement. When a student has a good performance in academic, it will affect his career adaptability. Research conducted by Subtirica and Pop (2016: 163) on the longitudinal relationship between career adaptability and academic achievement in adolescence showed that there is a positive reciprocal relationship on career dimension including concern, 


\section{COUNS-EDU}

Vol.1, No.1, December 2016

Available online: http://journal.konselor.or.id/index.php/counsedu

Mulawarman, et al.

control and confidence with academic achievement.The study results showed that adolescents with a strong future orientation, have career planning activities in school and high academic achievement reinforced by a positive outlook of the future.

College environment is important turning point for student life, because it is a transition period from high school to the college. College environment are more complex and problems susceptible for student. Students in the first year of the transition period will face many difficulties and problems in authonomy, interpersonal skills, and mental circumstances (Feng, 2015). The college also has identified strategies to address the needs of students during the second year. The second year is a time for students to develop goals and self-efficacy related to undergraduate education (Casper, et.al., 2011). This period is important because as a determinant period for the sustainability of a career in the next year. Second-year student its a periodof stressful time in university, because the academic demand is so high. Based on research, second year is very susceptible to dropout (Berkner et. A1., 2002; Hunter et. A1., 2010; in Casper in 2011 ). Approximately $60 \%$ of first-year students who achieve a GPA below 2.50 for the first half will not survive for third years (Undergraduate Education, University of Minnesota in 2011 in Casper et al, 2011).

First and second year in college have many challenges to be faced. The challenges can be divided into three main categories: academic, development, and institutional challenges (Pattengale 2000; Hunter et. A1., 2010; Casper, et.al., 2011). For example, student have to deal with different model of learning in the lecture. Developmental challenges such as transition periode of adolescence into adulthood affecting to the physical and psychological conditions. The example of institutional challenges is the college rules that are implemented to students. How individual face this challenge will determine the preparedness and resilience of student. Campus life environment requires students to be able to prepare and adjust to the environment.

Refers to several problem related to preparedness aspects career in student, it would require a psychological helping to facilitate the student to be more effective in addressing and developing skills in career. One of the psychological helping to facilitate students to develop an awareness of the potential, especially in terms of career is through the career counseling.

Based on empirical evidence, short-term counseling career-oriented is effective to overcoming career problems (Pedrix, Stauffer, Masdonati, Massoudi, and Rossier, 2012). One of the short-term or brief oriented approach to counseling is the Solution Focused Brief Counseling (SFBC). SFBC is one of Postmodern counseling approach emphasize to empowercounselee to find a solution, so that the counselee will choose their own goals to be accomplished (Corey, 2013; Gross, D. R., \&Capuzzi, D. 2007). SFBC has assumption that indiviual is healthy, competent, and have a capacity to build, design or construct the solutions. Individual do not focus to the problem, but focused on act and realize the solution he wanted.

Burwell and Chen (2006) suggested that career Solution Focused Brief Counseling (SFBC) effective to helping individual to solvecareer problems. The principles and techniques of the SFBC provides the direction to individuals to explore and develop his or her potential in order to obtain well-being living including career. So the purpose of this study was to examine the approach of Solution Focused Brief Counseling (SFBC) in developing student career adapatability.

\section{Method}

This research uses a mix method design. Mix method design is a combination between quantitative and qualitative research approaches including qualitative and quantitative research data on single study (Gay, Mills \&Airasian, 2009). One model of mixed method design is a embedded design model. Creswell and Clark (2007) explain that the embedded design is a form of mixed method design in which one data provide supporting data for other data. In other words, when a single data obtained from a research approach is inadequate because of the different types of data to be acquired, it is necessary to get additional data collected through other research method. So, data obtained is more comprehensive to explore one phenomenon.

Steps of embedded design in developing student career adaptability used solution focused brief counseling (SFBC): 


\section{Stage 1}

Researchers observe and interview students to know the initial conditions of career adaptability. To complement the qualitative data also used instruments Career Adapt-Abilities scale (CAAS) at the same time to select the students who will be the subject of research. Based on the interview (qualitative) and quantitative researchers chose a student to serve as research subjects (counselee) and ask them to filled informed consent.

\section{Stage 2}

In a second stage, research subject or counselee intervened by SFBC approach. During the intervention process also collected qualitative data in the form of counselee conversation analysis especially changes that lead to therapeutic purposes. Qualitative data taken are the result of counseling (or verbatim transcript) between the counselor (researcher) and counselee.

\section{Stage 3}

In the third stage, conducted qualitative data collection using focus group discussion to explore data related to extra therapeutic factors that drive career adaptability as the impact of SFBC approach interventions

Stage 4

The fourth stage of the embedded design is interpreting and explaining the results based on the qualitative and quantitative data. From this process, can be seen a counseling process, counselee development, and the effectiveness of interventions on achieving the goals of counseling comprehensively.

The population of this study were guidance and counseling department students particularly first and sophomore year in Faculty of Education Semarang State University. The subject of the research was student with lack of preparedness for the role change based on the early identification using interviews and career adaptability capabilities instrument indicated by the pessimistic attitude toward the future, the lack of ability to do the work, and lack of confidence. So, the sampling technique was purposive sampling.

The instrument used was a Career Adapt-Abilities scale (CAAS) which is used to identify and determine the readiness, resources, responses, and the results of adaptability (Savickas and Porfeli 2012). This instrument is the development of Porfeli and Savickas instruments. The instrument uses Likert scale with 5 scale that indicates the tendency of respondents to adaptability. Instrument reliability with Cronbach's alpha coefficient is 0.87 which is in high of reliability (Savickas and Porfeli 2012).

Two techniques data analysis was used. For qualitative data analysis used conversation analysis method and inferential statistical analysis non-parametric Wilcoxon Matched-pairs Signed-rank test used as quantitative data analysis. The Wilcoxon Matched-pairs Signed-ranks Test used to determine whether the changes in the subject of research occurs because interventions of SFBC with looking for the significance change between before and after the intervention. The result of pretest and posttest career adaptability can be seen in Table 1 .

Tabel 1 : Result of career adaptability pre-test and post-test

\begin{tabular}{cccc}
\hline No & Subject & Pre-test & Post-test \\
\hline 1 & Is & 67 & 81 \\
\hline 2 & Sw & 49 & 76 \\
\hline 3 & An & 62 & 80 \\
\hline 4 & Ai & 68 & 78 \\
\hline 5 & Jm & 73 & 85 \\
\hline & Mean & 64 & 80 \\
\hline
\end{tabular}

Analysis of the data used in the design of mixed based on two sources of data have been analyzed previously, quantitative analysis using statistical analysis and qualitative analysis using conversation analysis. Further analysis directed at the combined analysis of the two data sources. This analysis is called concurrent Data Analysis (Creswell and Clark, 2007). 


\section{Results and Discussions}

Based on pre-test, five subjects from the third semester chosen were detected are troubled with career adaptability. Fifth research subjects willing to participate in a series of research procedures. Both subjects had a score of adaptability is at low criteria in the range from 0 to 62.5 and three subjects in middle category because of the range of 62.5 to 75 . Based on interviews results conducted by the researcher, the researcher intervenes the subject using solution focused brief counseling approach. The number of counseling sessions conducted are three sessions counseling and two counseling sessions performed for fifth subjects. The number of counseling session conducted depend on the complexity of the adaptability careers problem of each subject. In general, the process of counseling done well, but there are some obstacles encountered from both researchers and subjects in the counseling process. The obstacles are more due to the time management from researcher and subject. After the counseling process, the researchers perform post tests using career adaptability scale) to find out how the level of career adaptability after SFBC approach intervention.

In conversation analysis showed changes in counselee speech along with its interpretation as seen from changes in speech on career adaptability towards responsible choices and plan for better and more productive activities. For the verbatim of the counselee is not included in this analysis but only picked out a conversation between counselee and counselor associated with the context of career adaptability.

This is the conversation analysis from forth subject that indicate confusion in time managementbetween organization and study.

"...I cannot manage the time between lectures and organization."

"... when the organization is better but the studies was a mess."

"..usually I can learn after the meeting, but now Icannot ..

"..often off from class because of the organization, often permission to the lectures,.."

"... when learn, my concentration was distracted because I've exhausted from the organization."

"there is positive and negative side to join organization to the study."

"..just learning in class time ..."

"... I do not take advantage of my free time to study but more focused on the organization .."

"... I should be noticed in order to manage the time ...

Some of subject statement indicating the adaptability career increasing are:

"...if I schedule my activities i have no load anymore sir.".

"Now my activity is more organized and go to class regularly ..."

"..i try to see the schedule and commit to do what is already scheduled .."

"..my parent help me to remind my activity..."

The statements of subject indicate that the subject has hopes to manage his time both in organization and in studies. From conversation analysis, five subject indicate career adaptability development. To analyze the quantitative data, hypotheses examined used Wilcoxon Signed-Rank Test. Wilcoxon SignedRank test was used to determine whether there are significant differences of career adaptability before and after the SFBC intervention.

Tabel 2. Result of Wilcoxon Signed-Rank Test on career adaptability

Post-test - pre-test

Z $-2.023^{a}$

Asymp. Sig. (2-tailed) .043

Based on result of Wilcoxon signed-rankest on career adaptability, showed thatasymp sig $=0,043<\alpha$ $=0,05$ it means that there is a significant different between student career adaptability before and after the solution focus brief counseling intervention. The conclusion is that according to quantitative analysis, solution focus brief counseling effective to develop student career adaptability. 
From quantitative and qualitative analysis, can be conclude that the intervention process by SFBC have an impact on subject career adaptability. These changes occur in the speech or action direct to career adaptability problem solving. Based on the results of the counseling process conducted by researchers then actually what happens in the intervention process and the results are achieved if it is associated with the common factors that marks the success of the counseling intervention SFBC is theoretically true. Lambert (1992) in Bertolino and O'Hanlon (2002: 15), states that the efficacy or effectiveness of counseling is determined more by the utilization of common therapeutic factors than by the embodiments of special therapeutic factors or specific techniques of counseling approach. General factors are basically summarized in three constructs: (1) extra therapeutic factors; (2) therapeutic relationship factors; (3) placebo or expectation factors. Factors extra therapeutic summarizes the counselee variables counselees to make improvements on her or his strength, or the ability to make changes to social support variables such as family or neighborhood.

Therapeutic relationship factors such as empathy, attention, unconditional positive regard, warmth and encouragement to develop embodied in the basic attitude of the counselor when helping the counselee to solve the problem. While the expectation factor such as hope and confidence of counselee and counselor to the efficacy, effectiveness, accuracy and the ability of the various aspects of counseling they together embodied in therapeutic process.

According to Lambert (1992) in Bertolino, B., \& O'Hanlon, W. H. (2002) suggests that the contribution of extra therapeutic factor, therapeutic relationship factors, hope and a special therapeutic factor to produce improvements in counselee has a different percentage. The largest contribution given by extra therapeutic factor is $40 \%$, followed by a therapeutic relationship factor of $30 \%$, and the expectation factor of $15 \%$. It can be said that the overall contribution of therapeutic factors that come from outside counseling to counselee improvement that hope factor is about $55 \%$.

From the theory of career adaptability point of view, career adaptability behavior of reasearch subject is the manifestation of behavioral choice to suffer or torment themselves. Glasser (Bertolino and O'Halan 2002) suggests that someone chooses a particular self-destructive behavior meet his needs rather than meet better needs. It can be seen when research subject tends to choose lazy behavior (subject 2). Subject feel that it needs she could meet in order to avoid more important needs (academic duties). In other words, that form of behavior used so that the subject does not do anything and afraid of doing something with big responsibilities.

In counseling session, the researchers help the subjects to assess their own behavior whether the behavior is strong enough to do the academic task and the behavior that lead to effective and responsible behavior. In this case the subject becomes aware of his behavior, although adaptabilities career behavior not completely changed but the subject began to realize ineffectiveness of their behavior. Sometimes individual not aware of ineffective behavior. According to Wubbolding (Bertolino and O'Halan, 2002) that occur because people do not study their selves or self-evaluation carefully to all behaviors that includes thoughts, feelings, actions and physiology.

\section{Conclusions}

Solution focus brief counseling approach effective to develop career adaptability of gudaince and counseling department faculty of education semarang state university. It is based on the result of quantitative and qualitative data analysis. From quantitative data analysis, wilcoxonsigned-ranktest on career adaptability showed that solution focus brief counseling effective to develop student career adaptability. From qualitative data analysis, conversation analysis showed desire and action of counselee to make career adaptability problem solution

\section{Acknowledgments}

We express our great appreciation to all of the children who participated and their friendly cooperation. 


\section{References}

Berkner, L., He, S., \& Cataldi, E. F. (2002). Descriptive Summary of 1995-96 Beginning Postsecondary Students: Six Years Later. Statistical Analysis Report.

Bertolino, B., \& O'Hanlon, W. H. (2002). Collaborative, competency-based counseling and therapy. Prentice Hall.

Bimrose, Jenny, Brown, Alan, Barnes, Sally-Anne, \& Deirdre, Hughes. (2011). "The role of career adaptability in skills supply". Report. University of Warwick. http://wrap.warwick.ac.uk

Burwell, R., \& Chen, C.P. (2006). Applying the principles and techniques of solution-focused therapy to career counselling. Counseling Psychology Quarterly, 19, (2), 189-203

Casper, Jeremy J., Khoury, Aron J., Lashbaugh, Kristy D., Ruesch, Alyssa M. (2011). "TheSophomoreYearExperience". Report. University of Minnesota.

Coolen, Anne Catharina Matheus. (2014). "Enhancing Career Adaptability to Prepare for the School to Work Transition: Outcomes of an e-Portfolio Intervention Among University Students". Thesis. UtrechtUniversity. dspace.library.uu.nl

Corey, Gerald. (2013). Theory and Practice of Counseling \& Psychotherapy (7 $7^{\text {th }}$ edition). Belmont, CA: Brooks/Cole

Creswell, John W., \& Clark, Vicki L. P. (2007). Designing and Conducting Mixed Methods Research. California: Sage Publications, Inc

Davies, P., \& Pearse, E. (2000). Success in English Teaching: A Complete Introduction to Teaching English at Secondary School Level and Above. Oxford University Press.

Feng, Zhao. (2015). "Analysis and Countermeasures of University Freshmen's Adaptability in China". Journal English Language Teaching, 3 (2): 5-8

Gay, L.R, Mills. G.E., \& Airasian, P.(2009). Educational Research:Competencies for Analysis and Applications (9th edition). New Jersey: Pearson Education, Inc.

Gross, D. R., \&Capuzzi, D. (2007). Helping relationships: From core dimensions to brief approaches. Counseling and psychotherapy: Theories and interventions, 3-25.

Heslin, P. A. (2005). Conceptualizing and evaluating career success. Journal of Organizational behavior, 26(2), 113-136.

Hirschi, A. (2009). "Career AdaptabilityDevelopmentinAdolescence:MultiplePredictorsandEffect onSenseofPowerandLifeSatisfaction.Journal of Vocational Behavior, 74 (2): 145-155.

Koen, J.(2013). "Prepare and Pursue: Routes to Suibtable (re-)Employment". Disertasi. University of Amsterdam: Psychology Research Institute. http://hdl.handle.net/11245/1.

O'Connell, Ryan M., et al. "MicroRNA-155 is induced during the macrophage inflammatory response." Proceedings of the National Academy of Sciences 104.5 (2007): 1604-1609.

Pedrix, S., Staufer, S., Masdonati, J., Massoudi, K., \&Rossier, J. (2012). Effectiveness of career counseling: A one-year follow-up. Journal of Vocational Behavior, 80, 565-578.

Savickas, Mark L. (1997). Carer Adaptability: An Integrative Construct for Life Span, Life-Space Theory. www.choixdecarriere.com

Zikic, J., \& Klehe, U. C. (2006). Job loss as a blessing in disguise: The role of career exploration and career planning in predicting reemployment quality. Journal of Vocational Behavior, 69(3), 391-409. 